Bangladesh J. Plant Taxon. 14(1): 13-24, 2007 (June)

\title{
AQUATIC FLORA IN TWO INDIAN PONDS NEAR KOLKATA, WEST BENGAL: IMPLICATIONS FOR CONSERVATION
}

\author{
Gautam Mukhopadhyay ${ }^{2}$, Sourav Sengupta And Anjana DewanjI ${ }^{1}$ \\ Agricultural and Ecological Research Unit, Indian Statistical Institute, 203 B.T. Road, \\ Kolkata 700 108, India
}

Key words: Aquatic flora, Species composition, Occurrence, Coverage, Nitrogen, Phosphorus, Management

\begin{abstract}
Occurrence, coverage and chemical constituents of aquatic flora were studied in two Indian ponds over a period of 39-month in order to gain an insight into their associations and infestation for implications in conservation and management. Species diversity was recorded in presence of two invasive species (Alternanthera philoxeroides (Martius) Griseb. and Lemna aequinoctialis Welwitsch). These species should be managed in view of their beneficial uses. Nymphaea pubescens Willd, a threatened species, was recorded. Positive association of Nymphoides hydrophylla (Loureiro) O. Kuntze with Alternanthera philoxeroides and Vallisneria spiralis L. showed that spatially separated habitats are useful for conservation. Azolla pinnata R. Brown, an useful species and Rotala rotundifolia (F. Hamilton ex Roxburgh) Koehne, an uncommon species, were able to produce high coverage in their brief occurrence - important for their conservation. Similar feature as observed in Cladophora glomerata (L.) Kütz and Hydrodictyon reticulatum (L.) Lagerh. is useful for management of these species due to their negative impacts.
\end{abstract}

\section{Introduction}

The State of West Bengal of India harbors nearly 57,000 small ponds (individual surface area $<2.25 \mathrm{ha}$ ). These ecosystems support 380 aquatic plant species belonging to 176 genera and 81 families which represent about $60 \%$ of the diversity of the Indian aquatic vascular plants (Cook 1996, Ghosh 2005). Being located in a monsoon region, the State supports a luxuriant growth of these plants throughout the year. Conservation of aquatic flora is an important part of the management regime of ponds in view of its regular use, specially by the villagers in rural landscapes. Aquatic plants also directly or indirectly provide fishes, birds, amphibians, reptiles and mammals with food, shelter and breeding sites, thus enhancing habitat diversity. They also support livelihood subsistence to several thousand rural folks in India and Bangladesh (Irfanullah 2002, Ghosh 2005).

In recent times, many species are gradually becoming rare in their earlier area of occurrence due to habitat modifications, overharvesting and invasion by exotic as well as aggressive weeds (Lacoul and Freedman 2006). Thus, aquatic plants are also directly threatened, sometimes even without coming to the knowledge of mankind (Cronk and Fennessy 2001). Record of different species of aquatic plants has been regarded as a

${ }^{1}$ Corresponding author, E-mail: anjana@isical.ac.in ${ }^{2}$ Department of Botany, Derozio Memorial College, Rajarhat, Kolkata 700 136, India. 
botanical conservation index for ponds (Linton and Goulder 2000). Charting the occurrence of individual species in a pond specially in presence of invasive weeds along with its phenology, coverage and chemical composition over time could provide valuable information on conservation and management related issues, options or strategies.

The knowledge of aquatic flora regarding the above-mentioned aspects is scarce particularly for pond ecosystems (Mukhopadhyay and Dewanji 2005) since they are primarily regarded to be a nuisance. Masses of vegetation are commonly eradicated from ponds to make the water body available for fishery practices. In view of the importance of aquatic plants, a baseline data on monthly variation in occurrence, phenology, coverage and nutrient contents of various species of aquatic flora found in two ponds near Kolkata, West Bengal were collected over a period of three years and three months in order to gain an insight into their conservation and management options or strategies.

\section{Materials and Methods}

Data were collected on a monthly basis, from March 1999 to May 2002 from two ponds, namely Pond 203 and Pond 206, situated within the Indian Statistical Institute campus in Baranagar, Kolkata, India (latitude $22^{0} 20^{\prime}-22^{0} 40^{\prime} \mathrm{N}$ and longitude $88^{0} 10^{\prime}-88^{0} 40^{\prime}$ E). Both ponds are old ( $>75$ years), rectangular in shape, small (surface area: 0.4 and 0.3 ha; volume: 7258 and $8136 \mathrm{~m}^{3}$, respectively) and shallow (maximum depth: 4.5 and 5.0 m, average depth: $2.2 \pm 1.8$ and $3.4 \pm 1.2 \mathrm{~m}$, respectively) with one inlet and one outlet. The surrounding land cover for both ponds is dominated by shading trees with overhanging branches, roads, nursery, temple and the ponds are primarily used by the local people as a water source for bathing, washing of clothes and utensils.

In this study, 'aquatic plants' will mean those plants, visible to the naked eye, that grow in the littoral zone of a water body and consisting of angiosperms, ferns and large freshwater algae.

Occurrence: Plant species were recorded by walking along the margin of the pond as well as by a boat. An Aquascope and a rake were used for observation and collection of submerged plants (Dennis and Isom 1984). Individual voucher specimen of each species was collected, dried and mounted on herbarium sheet (Martin 1995). Angiosperms and ferns were identified following Cook (1996), while macroalgae were identified according to Biswas and Calder (1955) and Boyd and Tucker (1998). Expert opinion was sought from the Central National Herbarium, Indian Botanic Garden, Sibpur, Howrah for reconfirmation of the identification.

Phenology: Monthly variations in leaf measurements of some dominant aquatic plant species were measured during a one-year period (May 1999 to April 2000). Period of flowering as well as fruiting was observed and recorded for each species. 
Cover percent: A stratified random design was used to determine monthly coverage of plants, present at six sampling points per pond, mainly at the littoral zone where majority of the plants occurred. It should be emphasized that the data collected therefore characterize the littoral zone, which in case of shallow ponds may be identical with the flora of the entire pond. At each sampling point, cover percent of each species was visually determined by placing a $1 \mathrm{~m}^{2}$ quadrat ten times (Srivastava et al. 1995) in three zones, namely, surface water - for floating plants; bottom - for submerged plants (Crawford 1977, Ali et al. 1999) and shoreline - for emergent plants, each to a maximum cover of $100 \%$.

Chemical composition: Plant samples were collected from six sampling points in each of two ponds. After removing excess water and debris, samples were dried in an oven at $70^{\circ} \mathrm{C}$ to constant weight. After drying, all samples were ground in a Cyclotec mill and used subsequently for chemical analysis following standard methods (AOAC 1984). Nitrogen (\% dry weight) was determined by the micro Kjeldahl method in a Kjeltec 1026 unit (Tecator, Höganäs, Sweden). Ash was estimated by incinerating plant sample at $550^{\circ} \mathrm{C}$ in a muffle furnace for 4-6 hrs. After ashing, samples were dissolved in nitric acid $(10 \% \mathrm{v} / \mathrm{v})$ and after dilution, the acid digest was used for determination of tissue phosphorus (\% dry weight) by colorimetric method (Fiske and Subbarow 1925).

Statistical analysis: Univariate description of cover percent and chemical constituents of different species of aquatic flora based on calculation of sample statistics such as mean, standard deviation, maximum and minimum values have been done on the complete dataset. To study the interrelationship between coverage of different species, Pearson's correlation coefficients were worked out.

\section{Results and Discussion}

Species list: A total of 13 plant species were recorded in the two ponds during the study period. The species list involved Alternanthera philoxeroides (Martius) Griseb. (Amaranthaceae), Azolla pinnata R. Brown ssp. asiatica (Azollaceae), Cladophora glomerata (L.) Kütz (Cladophoraceae), Commelina benghalensis L. (Commelinaceae), Eclipta alba (L.) Hasskarl (Asteraceae), Hydrodictyon reticulatum (L.) Lagerh. (Hydrodictyaceae), Lemna aequinoctialis Welwitsch (Lemnaceae), Marsilea minuta L. (Marsileaceae), Nymphaea pubescens Willd (Nymphaeaceae), Nymphoides hydrophylla (Loureiro) O. Kuntze (Menyanthaceae), Rotala rotundifolia (F. Hamilton ex Roxburgh) Koehne (Lythraceae), Trapa natans L. var. bispinosa (Roxb.) Makino (Trapaceae) and Vallisneria spiralis L. (Hydrocharitaceae).

Occurrence: The monthly occurrence of different plant species in the two study ponds is given in Fig.1. Occurrence of plant species $\geq 50 \%$ of the study period was considered to be the dominant flora while the rest was regarded as less dominant ones. 
Less dominant Flora

Azolla pinnata (13)

Cladophora glomerata (5)

Commelina benghalensis (28)

Marsilea minuta (46)

m Nymphaea pubescens (49)

ㄱ Rotala rotundifolia (36)

7 Trapa natans (8)

ชุ

Dominant Flora

Alternanthera philoxeroides (54)

Lemna aequinoctialis (97)

Nymphoides hydrophylla (100)

Vallisneria spiralis (100)

Dominant Flora

Alternanthera philoxeroides (54)

Lemna aequinoctialis (61)

Nymphoides hydrophylla (54)

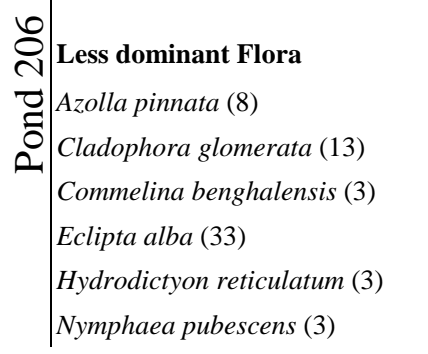

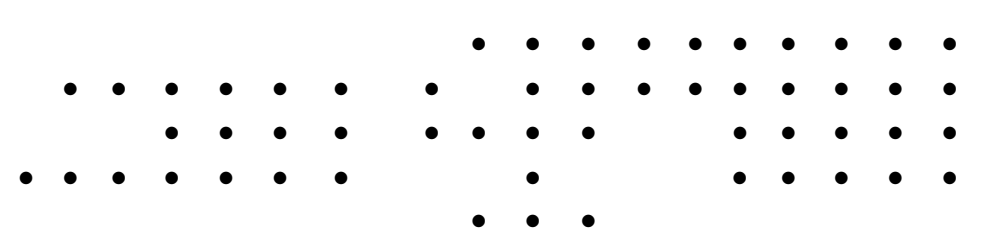

- $\bullet$

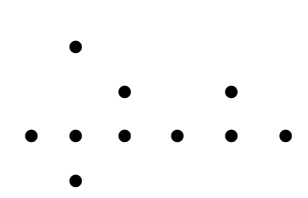

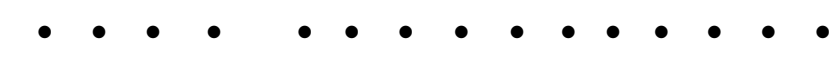

$\bullet \bullet \bullet \bullet \bullet \bullet \bullet \bullet-$

$\bullet \bullet \bullet \bullet \bullet \bullet \bullet \bullet$

$\bullet \bullet \bullet \bullet \bullet \bullet \bullet \bullet \bullet$

\begin{tabular}{lllllllllllllll}
$M$ & $A$ & $M$ & $J$ & $J$ & $A$ & $S$ & $O$ & $N$ & $D$ \\
\hline
\end{tabular}

0

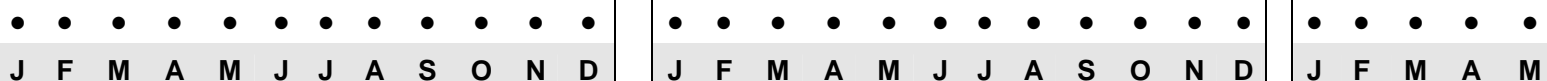

\begin{tabular}{|llllllllllll|}
\hline & $F$ & $M$ & $A$ & $M$ & J & J & A & S & O & N & D \\
\hline
\end{tabular}

$\bullet \bullet \bullet$

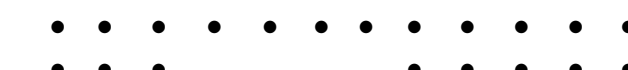

$\bullet \bullet$

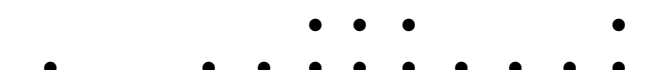

$\bullet \bullet \bullet \bullet \bullet \bullet \bullet \bullet$

-

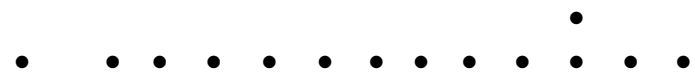

Fig. 1. Monthly occurrence of plants (March 1999 - May 2002) in Ponds 203 and 206 (Figures in parentheses show the percent occurrence for each plant). 
Among the dominant species, Alternanthera philoxeroides grew in relatively monospecific stands along the banks of both ponds during September 1999 to December 2000. At times (June to October), it extended to a considerable distance (1 m from bank) across the water surface by developing buoyant layers. Lemna aequinoctialis was present throughout the study period in Pond 203, gregariously forming a green mantle on the surface during July to November. Nymphoides hydrophylla was present throughout the study period in Pond 203 and from January 2000 to August 2001 in Pond 206. Vallisneria spiralis was present throughout the study period as a thick vegetation bed (up to a depth of $2 \mathrm{~m}$ ) in the littoral zone of Pond 203.

Among the less dominant species, Azolla pinnata was found in both ponds during the last three months (March to May 2002) of the study period. In India, large-scale growth of this species has been reported and it was found that during the growing season (winter) it can double its weight in less than 7 days (Gopal 1967). Cladophora glomerata was found forming dense filamentous cushion on soft substrates at a maximum depth of 20 $\mathrm{cm}$ in the littoral zone of Pond 203 in February and March 2001, while it occurred for brief periods during the years 2001 and 2002 in Pond 206. In temperate ponds, vegetative growth was recorded during early summer (Mason 1965). Propagation by overwintering filaments possibly reestablished the species in the subsequent year in Pond 206. Commelina benghalensis was noticed only once in October 2000 in Pond 206, while it was present for a longer stretch (February to November 2000) in Pond 203. During the monsoons, this plant extended into the water in Pond 203 by its creeping stems rooting at the nodes. Eclipta alba was observed only in Pond 206 from December 1999 to December 2000. Ramakrishnan (1960) found that the incidence of this species was higher at the end of the rainy and winter seasons. Hydrodictyon reticulatum made an appearance in submerged condition at a maximum depth of $0.5 \mathrm{~m}$ in the littoral zone during February 2001 in Pond 206. In some temperate regions, the species is reported to form extensive surface mats during summer on a regular basis (Wells and Clayton 2001). Marsilea minuta was present only in Pond 203 mainly during July 1999 to November 2000. The floating leaves of Nymphaea pubescens were noticed only once in October 2001 in Pond 206, while it grew intermittently along the littoral zone in Pond 203. This species has been regarded to be threatened in West Bengal (Ghosh 2005). Bushy growth of Rotala rotundifolia was observed up to $2 \mathrm{~m}$ depth in the littoral zone of Pond 203, mostly during the years 1999 and 2000. The species has been reported to be uncommon in West Bengal (Ghosh 2005). Although Pond 203 was not used for cultivation of Trapa natans, the species was observed at only one location for a brief period (February to April 2000). In tropical climates, maximum growth of this species has been observed during winter (Kumari and Datta Munshi 1991), while in temperate ponds, the time was generally summer (Kunii and Maeda 1982). 
Phenology: Monthly variation of leaf measurements of three dominant species in Pond 203 during May 1999 to April 2000 is given in Fig. 2. Fronds of Lemna aequinoctialis were 0.4 to $3.0 \mathrm{~mm}$ long (Fig. 2a) and 0.3 to $2.0 \mathrm{~mm}$ wide. Maximum frond length was observed during January. Blades of floating leaves of Nymphoides hydrophylla were 1.8 to $15.0 \mathrm{~cm}$ wide and maximum value was observed during May (Fig. 2b). Leaves of Vallisneria spiralis were 8.4 to $82.8 \mathrm{~cm}$ long, 3.0 to $9.0 \mathrm{~mm}$ wide (Figs. 2c- d). Higher values of leaf length were observed from May to September, while
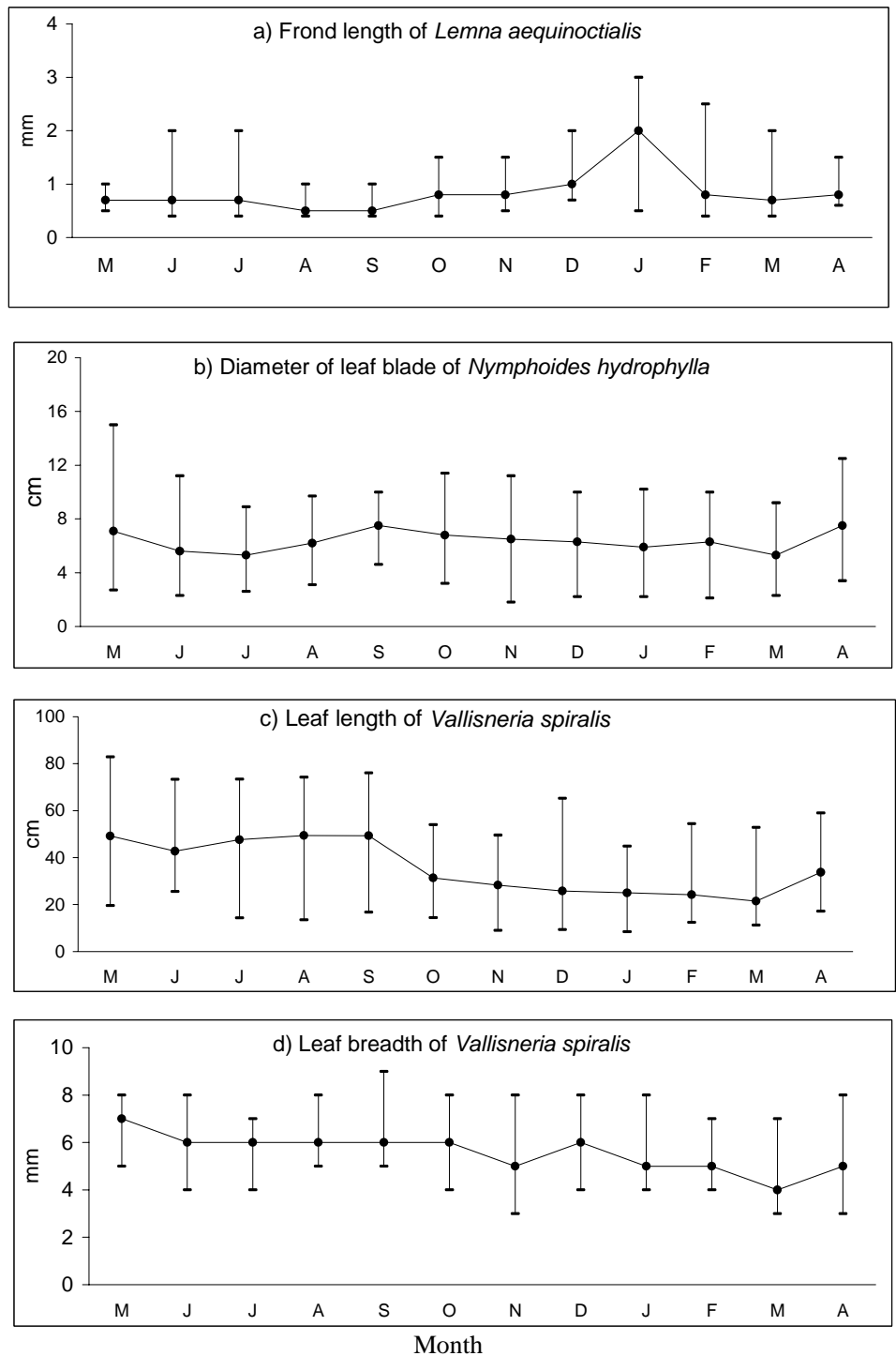

Fig. 2. Monthly variation in leaf measurements of three dominant aquatic plant species a) Lemna aequinoctialis, b) Nymphoides hydrophylla and c-d) Vallisneria spiralis in Pond 203 from May 1999 to April 2000. 
leaf breadth was comparatively stable and always $<10 \mathrm{~mm}$. Cook (1996) reported that leaves might be up to $2 \mathrm{~m}$ long. As per Lowden's classification (1982), the plant found in the present study fell into the narrow leaved $(<10 \mathrm{~mm}$ width) category.

Only flowering was recorded for Alternanthera philoxeroides (throughout the year), Nymphoides hydrophylla (throughout the summer and winter months), Vallisneria spiralis (only staminate flowers were observed throughout the year), Commelina benghalensis (aerial chasmogamous flowers were found throughout the presence of the plant) and Eclipta alba (during August). In case of Nymphaea pubescens both flowers (during the rainy season) and fruits (during November) were observed.

Cover percent: The mean cover percent values of all the plants found in this study are reported in Table 1 along with their maximum values to give an idea about their potential for maximum coverage. It can be seen that all dominant flora had maximum values

Table 1. Mean and maximum cover percent of aquatic plants of the two study ponds (Ponds 203 and 206).

\begin{tabular}{|c|c|c|c|c|}
\hline Species & $\begin{array}{l}\text { Total number of } \\
\text { months present }\end{array}$ & Pond & Mean \pm SD & Maximum \\
\hline \multicolumn{5}{|l|}{ Dominant plant } \\
\hline \multirow{2}{*}{ Alternanthera philoxeroides } & 21 & 203 & $28.1 \pm 16.37$ & 72 \\
\hline & 21 & 206 & $28.6 \pm 23.04$ & 82 \\
\hline \multirow{2}{*}{ Lemna aequinoctialis } & 38 & 203 & $31.2 \pm 28.60$ & 100 \\
\hline & 24 & 206 & $34.8 \pm 37.90$ & 100 \\
\hline \multirow{2}{*}{ Nymphoides hydrophylla } & 39 & 203 & $15.8 \pm 14.56$ & 77 \\
\hline & 21 & 206 & $24.6 \pm 21.08$ & 91 \\
\hline Vallisneria spiralis & 39 & 203 & $61.7 \pm 27.08$ & 98 \\
\hline \multicolumn{5}{|l|}{ Less dominant plant } \\
\hline \multirow{2}{*}{ Azolla pinnata } & 5 & 203 & $34.6 \pm 30.50$ & 81 \\
\hline & 3 & 206 & $38.0 \pm 50.70$ & 98 \\
\hline \multirow{2}{*}{ Cladophora glomerata } & 2 & 203 & $36.0 \pm 8.60$ & 70 \\
\hline & 5 & 206 & $18.0 \pm 22.20$ & 89 \\
\hline \multirow{2}{*}{ Commelina benghalensis } & 11 & 203 & $1.9 \pm 2.39$ & 35 \\
\hline & 1 & 206 & $1.0 \pm 0.01$ & 3 \\
\hline Eclipta alba & 13 & 206 & $3.7 \pm 3.82$ & 28 \\
\hline Hydrodictyon reticulatum & 1 & 206 & $39.0 \pm 7.67$ & 78 \\
\hline Marsilea minuta & 18 & 203 & $3.1 \pm 2.40$ & 30 \\
\hline \multirow{2}{*}{ Nymphaea pubescens } & 19 & 203 & $1.1 \pm 0.46$ & 10 \\
\hline & 1 & 206 & $1.0 \pm 0.07$ & 2 \\
\hline Rotala rotundifolia & 14 & 203 & $13.1 \pm 9.93$ & 76 \\
\hline Trapa natans & 3 & 203 & $1.0 \pm 0.22$ & 2 \\
\hline
\end{tabular}

above $70 \%$. Among the less dominant flora, Azolla pinnata, Cladophora glomerata, Hydrodictyon reticulatum and Rotala rotundifolia also showed maximum cover above $70 \%$ during their limited period of existence. Mean values of cover percent of Azolla pinnata (both ponds), Cladophora glomerata (Pond 203), and Hydrodictyon reticulatum 
(Pond 206) were found to be higher than that of dominant species like Alternanthera philoxeroides, Lemna aequinoctialis and Nymphoides hydrophylla in respective pond/ponds, which could be due to their abilities of formation of extensive colonies even for a short duration. However, Commelina benghalensis and Nymphaea pubescens in Pond 206 and Trapa natans in Pond 203 showed minimum cover percentage during their brief appearence. Among the dominant flora, cover percent of Nymphoides hydrophylla was positively associated with that of Alternanthera philoxeroides and Vallisneria spiralis ( $r=0.332$ and 0.447 , respectively, $n=39, P<0.05$ ). The coexistence of dominant plants in these ponds could be due to the fact that growth habits of floating, submerged and emergent forms were spatially separated from each other and probably had better availability of abiotic resources in the system (Chambers and Prepas 1990).

Chemical composition: The chemical composition of the different plants found in the study was analyzed and the results are reported in Table 2. Nitrogen in aquatic plants ranged from 0.78 in Cladophora glomerata to 3.08\% in Azolla pinnata in the two ponds, while phosphorus content varied from $0.03 \%$ in Cladophora glomerata to $0.36 \%$ in Rotala rotundifolia in the two ponds. All the dominant species in both ponds showed

Table 2. Dry matter, nitrogen and phosphorus estimation of aquatic plants of two ponds (Ponds 203 and 206).

\begin{tabular}{lcrrrc}
\hline Plant & Pond & $\mathrm{n}$ & $\begin{array}{c}\text { Dry matter } \\
(\%)\end{array}$ & Nitrogen (\%) & $\begin{array}{c}\text { Phosphorus } \\
(\%)\end{array}$ \\
\hline \multirow{2}{*}{ Alternanthera philoxeroides } & 203 & 71 & $12.3 \pm 3.2$ & $2.23 \pm 0.81$ & $0.22 \pm 0.07$ \\
& 206 & 66 & $12.1 \pm 2.8$ & $2.39 \pm 1.05$ & $0.20 \pm 0.10$ \\
\hline \multirow{2}{*}{ Azolla pinnata } & 203 & 14 & $5.9 \pm 0.8$ & $2.76 \pm 0.31$ & $0.23 \pm 0.17$ \\
& 206 & 6 & $7.5 \pm 0.6$ & $3.08 \pm 0.18$ & $0.11 \pm 0.02$ \\
\hline \multirow{2}{*}{ Cladophora glomerata } & 203 & 2 & $13.6 \pm 4.3$ & $0.78 \pm 0.13$ & $0.03 \pm 0.01$ \\
& 206 & 16 & $10.4 \pm 2.3$ & $2.56 \pm 0.61$ & $0.27 \pm 0.07$ \\
\hline \multirow{2}{*}{ Commelina benghalensis } & 203 & 13 & $11.4 \pm 5.0$ & $1.97 \pm 0.66$ & $0.29 \pm 0.10$ \\
\hline Eclipta alba & 206 & 2 & $8.7 \pm 0.3$ & $1.34 \pm 0.11$ & $0.28 \pm 0.06$ \\
\hline Hydrodictyon reticulatum & 206 & 19 & $14.6 \pm 3.1$ & $0.96 \pm 0.54$ & $0.11 \pm 0.08$ \\
\hline \multirow{2}{*}{ Lemna aequinoctialis } & 206 & 4 & $5.7 \pm 0.8$ & $1.73 \pm 0.48$ & $0.13 \pm 0.15$ \\
\hline Marsilea minuta & 203 & 111 & $7.0 \pm 2.5$ & $2.32 \pm 0.57$ & $0.31 \pm 0.13$ \\
\multirow{2}{*}{ Nymphoides hydrophylla } & 206 & 89 & $7.0 \pm 1.2$ & $2.50 \pm 0.58$ & $0.27 \pm 015$ \\
\hline Rotala rotundifolia & 203 & 12 & $9.8 \pm 2.8$ & $1.82 \pm 0.97$ & $0.26 \pm 0.08$ \\
\hline Vallisneria spiralis & 203 & 110 & $9.4 \pm 2.6$ & $2.08 \pm 0.67$ & $0.33 \pm 0.10$ \\
\hline
\end{tabular}

higher nutrient values than the growth limiting levels (1.3 and 0.13\% dry weight respectively for nitrogen and phosphorus) reported by Gerloff and Krombholz (1966). Similar values were found for less dominant species except Eclipta alba, Azolla pinnata (for phosphorus) and Cladophora glomerata only in Pond 203 (Table 2). 
Implications for conservation: The present study gives us an insight into the natural succession of species in two ponds over a 39-month period. From the data, we can get an idea about species occurrence, their associations and dominance which could help us plan conservation and management measures in future.

Throughout the study period the use of both ponds for anthropogenic purposes continued unabated thereby showing that the growth of plants, however much or little, maintained equilibrium with water use. Since all the dominant flora belonged to different families and growth forms, they could maintain species diversity and ecosystem function and health probably because of their spatially separated habitats.

Among the dominant flora, Alternanthera philoxeroides and Lemna aequinoctialis, because of their potential to grow in conducive conditions, need management in view of their use as food and feed. Studies done in our laboratory have also shown the potential of Lemna aequinoctialis as a source of biofertilizer (Sengupta et al. 2005a) as well as for possible control of eutrophication of pond ecosystems (Sengupta et al. 2005b). Nymphoides hydrophylla was never found to grow to nuisance proportion unlike its temperate counterpart, Nymphoides peltata (Brock et al. 1983) and hence should be conserved in view of its beneficial use as food, medicine and beautification (Ghosh 2005). The ability of Vallisneria spiralis to maintain water transparency even at high phosphorus concentrations thereby retarding algal blooms has been reported by Mukhopadhyay and Dewanji (2004). Xian et al. (2006) identified allelochemicals from the extracts of this plant which had strong inhibitory effects on colonial cyanobacteria Microcystis. Thus presence of V. spiralis only in Pond 203 is thereby beneficial, and could be a cause of greater diversity in this pond.

Among the less dominant species, Azolla pinnata and Marsilea minuta, the sole representatives of the families Azollaceae and Marsileaceae in West Bengal, were also recorded. Occurrence, ability to grow (maximum coverage $270 \%$ ) even in the presence of competitive association of Lemna aequinoctialis is important in view of the conservation of Azolla pinnata, which is a potential source of biofertilizer. In the present study, Marsilea minuta was also found in association with diverse plant communities like Commelina benghalensis, Nymphaea pubescens, Rotala rotundifolia, Nymphoides hydrophylla and Vallisneria spiralis. Similar association was reported by Ghosh (2005) in various fish ponds where the presence of $M$. minuta in non-netting zones enhanced biodiversity without disturbing fishery practices. The other major association consisted of Lemna aequinoctialis (free-floating), Nymphoides hydrophylla and Nymphaea pubescens (rooted-floating) for shared resources and nutrient status. The association evident between two emergent plants Eclipta alba and Alternanthera philoxeroides could probably be explained by their tissue nitrogen and phosphorus contents. Eclipta alba with its low requirement of these nutrients could flourish in presence of A. philoxeroides, which had a comparatively higher nitrogen and phosphorus contents. 
Nymphaea pubescens, one of the two species of the genus Nymphaea generally observed in West Bengal, is now considered as 'threatened' because of indiscriminate harvesting of rhizomes as alternative vegetables and source of medicine in rural Bengal (Ghosh, 2005). The presence of this species in Pond 203 adds to the diversity. Rotala rotundifolia was also found in Pond 203 and hence gave us an opportunity to study its occurrence (present 14 months in a 39-month study period), coverage (ability to grow to $\geq 70 \%$ coverage occasionally) and its associations (ability to share space with other submerged plants like Vallisneria spiralis and Cladophora glomerata). Mean nitrogen and phosphorus percent was found to be highest in $R$. rotundifolia when compared with the two other submerged species of this pond, namely $V$. spiralis and C. glomerata.

Conservation strategies for the growth of Nymphaea pubescens for its use as food, Eclipta alba for its medicinal values and Rotala rotundifolia which is uncommon in this region, should be developed. On the contrary, Cladophora glomerata and Hydrodictyon reticulatum - the scum forming algae should also be managed since they can grow to nuisance proportions causing problems for boating, fisheries and water supply.

Phenology of different species showed that the majority of plants reproduced by vegetative structures, thus regular observation of these structures specially for less dominant species is also important for their conservation. A regular record of aquatic plants in ponds should therefore be maintained in order to get an insight into the regional diversity as well as for initiating future conservation and management for the proper health and functioning of pond ecosystems.

\section{Acknowledgements}

Thanks are due to L.B. Magranti and G. Bhaumik for providing all possible assistance during the fieldwork. We also gratefully acknowledge experts of the Central National Herbarium, Indian Botanic Garden, Sibpur for their help in reconfirming the identification of some aquatic plant species.

\section{References}

Ali, M.M., Murphy, K.J. and Abarnethy, V.J. 1999. Macrophyte functional variables versus species assemblages as predictors of trophic status in flowing waters. Hydrobiologia 415: 131-138.

AOAC 1984. Official Methods of Analysis (Horwitz, W. ed.) $14^{\text {th }}$ edn. Association of Official Analytical Chemists, Washington DC, pp. 1141.

Biswas, K. and Calder, C.C. 1955. Hand book of common water and marsh plants of India and Burma 1936. Health Bull No. 24, Malaria Bureau No.11, Manager of Publication, Delhi, pp. 216.

Boyd, C.E. and Tucker, C.S. (Eds.) 1998. Pond Aquaculture Water Quality Management. Kluwer Academic Publishers, Boston, pp. 396-397.

Brock, T.C.M., Arts, G.H.P., Goosen, I.L.M. and Rutenfrans, A.H.M. 1983. Structure and biomass production of Nymphoides peltata (Gmel.) O. Kuntze (Menyenthaceae). Aquat. Bot. 17(3-4): 167-188.

Chambers, P.A. and Prepas, E.E. 1990. Competition and coexistence in submerged plant communities: the effects of species interaction versus abiotic factors. Freshwater Biol. 23(3): 541-550. 
Cook, C.D.K. 1996. Aquatic and Wetland Plants in India. Oxford University Press, Oxford, pp. 385.

Crawford, S.A. 1977. Chemical, physical and biological changes associated with Chara succession in farm ponds. Hydrobiologia 55(3): 209-217.

Cronk, J.K. and Fennessy, M.S. 2001. Wetland Plants: Biology and Ecology. CRC Press, Boca Raton, pp. 462.

Dennis, W.M. and Isom, B.G. 1984. Ecological Assessment of Macrophyton: Collection, Use and Meaning of Data. ASTM STP 843, American Society for Testing and Materials, Philadelphia, pp. 122.

Fiske, C.H. and Subbarow, Y. 1925. The colorimetric determination of phosphorus. J. Biol. Chem. 66(2): $375-400$.

Gerloff, G.C. and Krombholz, P.H. 1966. Tissue analysis as a measure of nutrient availability for the growth of aquatic angiosperm plants. Limnol. Oceanogr. 11: 529-537.

Ghosh, S.K. 2005. Illustrated Aquatic and Wetland Plants in Harmony with Mankind. Standard Literature, India, pp. 225.

Gopal, B. 1967. Contribution of Azolla pinnata R.Br. to the productivity of temporary ponds at Varanashi. Trop. Ecol. 8: 126-130.

Irfanullah, H.M. 2002. Studies on aquatic vascular plants in Bangladesh: an appraisal. Bangladesh J. Plant Taxon. 9 (1): 85-116.

Kumari, N. and Dutta Munshi, J. 1991. Monthly variation in biomass of a floating-leaved plant, Trapa bispinosa Roxb. in a wetland of Bhagalpur in relation to abiotic factors. J. Freshwater Biol. 3: 309-313.

Kunii, H. and Maeda, K. 1982. Seasonal changes in surface cover of aquatic plants in a shallow pond, Ojagaike, Chiba, Japan. Hydrobiologia 37(1): 45-55.

Lacoul, P. and Freedman, B. 2006. Environmental influences on aquatic plants in freshwater ecosystems. Environ. Rev. 14: 89-136.

Linton, S. and Goulder, R. 2000. Botanical conservation value related to origin and management of ponds. Aquat. Conserv. Mar. Freshwater Ecosystem 10(2): 77-91.

Lowden, R.M. 1982. An approach to the taxonomy of Vallisneria L. (Hydrocharitaceae). Aquat. Bot. 13: 269-298.

Martin, G.J. (Ed.) 1995. Ethnobotany: A Methods Manual. Chapman and Hall, London, pp. 31-54.

Mason, C.P. 1965. Ecology of Cladophora in farm ponds. Ecology 46(2): 421-429.

Mukhopadhyay, G. and Dewanji, A. 2004. The ability of aquatic macrophytes to maintain water clarity in two tropical ponds. Intern. J. Environ. Studies 61(5): 579-586.

Mukhopadhyay, G. and Dewanji, A. 2005. Presence of tropical hydrophytes in relation to limnological parameters - a study on two freshwater ponds in Kolkata, India. Ann. Limnol. 41(4): 281-289.

Ramakrishnan, P.S. 1960. Ecology of Eclipta alba Hassk. Proc. Nat. Ins. Sci. India, 24B: 191-204.

Sengupta, S. Mukhopadhyay, G. and Dewanji, A. 2005a. Lemna aequinoctialis, a cheap source of biofertilizer. In: Mathur, S.M., Mathur, A.N., Trivedy, R.K., Bhatt, Y.C. and Mohnot, P. (eds.), Aquatic Weeds: Problems, Control and Management. Himanshu Publications, New Delhi, India, pp. 60-66.

Sengupta, S. Mukhopadhyay, G. and Dewanji, A. 2005b. Potentiality of Lemna aequinoctialis in controlling eutrophication. In: Banerjee, A., Mallic B., Sarkar D., Datta H., Chakrabarti J., Bhattacharya P., Mandal R. and Mandal S. (eds.), Combating Disaster Perspectives in the new millennium. ACB Publications, Kolkata, India, pp. 387-390.

Srivastava, D.S., Cynthia, A. and Staicer, B.F. 1995. Aquatic vegetation of Nova Scotian lakes differing in acidity and trophic status. Aquat. Bot. 51(3-4): 181-196. 
Wells, R.D.S. and Clayton, J.S. 2001. Ecological impact of water net (Hydrodictyon reticulatum) in Lake Aniwhenue, New Zealand. N. Z. J. Ecol. 25(2): 55-63.

Xian, Q., Chen, H., Liu, H., Zou, H. and Yin, D. 2006. Isolation and identification of antialgal compounds from the leaves of Vallisneria spiralis L. by activity guided fractionation. Environ. Sci. Pollut. Res. 13(4): 233-237.

(Manuscript received on 6 March 2007; revised on 10 April 2007) 